\title{
Corporate Social Responsibility and the Reciprocity Between Employee Perception, Perceived External Prestige, and Employees' Emotional Labor
}

This article was published in the following Dove Press journal:

Psychology Research and Behavior Management

Muhammad Aamir Shafique Khan (iD) 1,2 Jianguo Du'

Farooq Anwar ${ }^{2}$

Hira Salah ud Din Khan (iD)

Fakhar Shahzad (D)'

Sikandar Ali Qalati (iD)

'School of Management, Jiangsu University, Zhenjiang, Jiangsu, People's Republic of China; ${ }^{2}$ Lahore Business School, University of Lahore, Lahore, Punjab, Pakistan
Correspondence: Jianguo Du School of Management, Jiangsu University, Zhenjiang, Jiangsu, People's Republic of China Tel +86-157-5100-8313

Email dujianguoju@hotmail.com
Background: Corporate social responsibility (CSR) is emerging as a relevant subject in the business world and in the field of management research. Therefore, the current study incorporates classifications often used in organizational level CSR research that distinguish social responsibility relevant to its focus (internal and external), in proposing diverse routes that link various CSR practices (ie, internal and external) to employees' choice of emotional labor strategy (ie, via perceived organizational support and perceived external prestige).

Methods: Data were collected from front-line employees of banks operating in Pakistan. Due to the study's focus on front-line employees, other personnel were excluded for data collection. We collected data through a self-administered questionnaire. The structural equation model (SEM) was employed on 376 valid responses using Smart-PLS3 to test the study hypotheses.

Results: After the analysis, we found satisfactory results for the fitness of both measurement and satisfactory models. Moreover, the results strongly support our proposed theoretical framework, and all proposed hypotheses were accepted.

Discussion: This study confirms that the perception of external prestige is a strong predictor of employees' emotions and relevant behaviors. Moreover, this study discusses under the light of social exchange theory that perceived organizational support strongly predicts employees' emotional labor, which diminishes the myth that prestige is the only factor to influence employees' emotions in the workplace. Moreover, this study negates the findings of Anwar et al that perceived external prestige does not have a significant negative effect on surface acting. It provides an insight not only for managers and researchers but also for society, especially in an Eastern workplace setting like Pakistan's banking sector.

Keywords: CSR, perceived external prestige, perceived organizational support, emotional labor, employees' welfare

\section{Introduction}

Corporate social responsibility (CSR) is emerging as a relevant subject in the business world and in the field of management research. ${ }^{1-4}$ Prior research on firm perspectives of CSR provides contradictory results of its impact on organizational financial performance. ${ }^{5,6}$ Furthermore, organizational performance majorly depends on employees' behaviors and these behaviors have strong relationships with the psyche of employees. ${ }^{4}$ Similarly, employees' behaviors are also triggered by 
organizational activities for their stakeholders. ${ }^{7}$ Consequent studies proposed to flip the theoretical lens to understand CSR contribution to organizational performance by incorporating stakeholder's attitudes and behaviors as a mediating mechanism. ${ }^{7,8}$ Employees as primary ${ }^{9}$ and essential stakeholders influence organizational financial performance, ${ }^{10,11}$ Research also suggests that the status of being socially responsible is vital to improve employees' attraction, satisfaction, and commitment to organization. $^{12,13}$

Notwithstanding the plethora of submissions, only a few studies, focusing on incumbent employees, ${ }^{14-16}$ investigated CSR impact on their attitudes and behaviors. However, underlying the psychological mechanism through which CSR can build observable employee attitudes and behaviors is still vastly unknown, 2,17,18 Employees develop an imperative stakeholder group relevant to determinants and outcomes of CSR. ${ }^{19}$ Further, scholars stressed on the mechanism to link CSR with desired employee outcomes (ie, attitudes and behaviors) and emotional labor. ${ }^{20}$ This study addresses the problem of internal and external CSR concerning deep acting, surface acting, and employees' perception of external prestige. Moreover, we focus on the problems of employee perception on internal CSR towards the perception of perceived organizational support; and perceived external prestige and organizational support's mediation to deep and surface acting. Frontline banking staff are the primary point of rendering services and frequent customer interaction, and involves emotional labor. The rising competition in the banking industry has compelled the frontline staff to deal with customers more gently and calmly, irrespective of their personal feelings. Therefore, they face issues to regulate their emotions. $^{21}$

Literature has evidenced the phenomenon that employees' emotions and their management play an imperative role in the workplace. For instance, emotional labor as a management of expression affects major employee attitudes like job satisfaction, ${ }^{22,23}$ role identification, ${ }^{24}$ and organizational commitment. $^{25}$ Previous literature on emotional labor mostly focused on individual level analysis. ${ }^{26,27}$ Therefore, less has been known about its interaction with organizational factors. $^{20,28}$ Moreover, studies regarding the predictors of emotional labor and various mechanisms of these relationships are needed to understand the psychological and behavioral demands of employees. Specifically, these mechanisms needed to be uncovered in Asian countries, where people deal with more emotions due to the collectivist culture and expectations from their organizations to work for their welfare. ${ }^{28}$ Furthermore, it is also endorsed in the literature that further research using data from subjects with different cultural orientation is thus required to confirm the external validity for the results of the aforementioned variables. ${ }^{20}$ Therefore, the current study, specifically in an Asian context, incorporates classifications often used in organizational level CSR research that distinguish social responsibility relevant to its focus (internal and external), ${ }^{29}$ in proposing diverse routes that link various CSR practices (ie, internal and external) to employees' choice of emotional labor strategy (ie, via perceived organizational support and perceived external prestige). Furthermore, front-line employees' issues are mostly occurring in the services sector because services sector employees have more interaction with customers than the manufacturing sector. Correspondingly, the economy of developing countries majorly depends on the services sector, and the banking sector is considered the major part of the services industry in Asian countries. Therefore, this study focuses on the front-line employees of the banking sector.

First, this study aims to evaluate external and internal CSR's effects on deep acting and surface acting, respectively. Second, we aim to explore the effects of employee perception of external and internal CSR on employee's perception and perceived organizational support, singly. Finally, we propose the mediating mechanism of perceived external prestige (between employee perception of CSR, deep acting and surface acting), and perceived organizational support (amongst the relationships of internal CSR, emotional labor, deep and surface acting, respectively).

Such a study is vital for both theoretical and practical reasons. First, unlike in the past, ${ }^{30} \mathrm{CSR}$ is not a unitary construct anymore, where CSR perception generally predicts employee attitudes and behaviors. Recent studies by El Akremi et al, ${ }^{31}$ along with Turker's ${ }^{19}$ multi-stakeholders view suggest that employees observe CSR activities of their employers as a set of activities targeting different stakeholder groups and express their response accordingly.

Second, the current study extends the CSR literature by responding to the call for investigation by $\mathrm{Oh}$ et $\mathrm{al}^{20}$ and Glavas $^{2}$ by including actual human perspectives (ie, emotional labor) in the existing CSR mechanism to identify the pathways of CSR activities and choice of emotional labor strategy. As per our understanding, the current study is the first attempt to develop and evaluate different routes to 
emotional labor via the perception of CSR (internal and external), which has received less empirical attention in the past. ${ }^{17,18}$

\section{Literature Review Corporate Social Responsibility}

The concept of CSR and its definition have evolved in the past couple of decades. ${ }^{32}$ Despite numerous efforts there is a lack of a commonly accepted definition of CSR in the corporate and academic world. ${ }^{19,33}$ Defining CSR is complicated owing to diverse interpretations like "essentially contested concept", "internally complex", and "open rules of application". ${ }^{34}$ The conceptual model of the study is shown as Figure 1.

CSR involves different definitions of certain legal and economic responsibilities and obligations to stakeholders to wider responsibilities to the broader social structures in which a company is rooted. ${ }^{35}$ Given this, the emphasis is on the relationship between business and society, and businesses that strive to distinguish themselves by participating in what has been alluded to as CSR. ${ }^{36}$ CSR is defined as

The social responsibility of a business encompassing the economic, legal, ethical and discretionary expectations that a society has of the organizations at a given point in time. $^{37}$

However, many other scholars have a contradictory opinion about Carroll's definition of CSR, they argue that legal, technical, and economic responsibilities should be excluded from CSR definition. ${ }^{38}$ Carroll $^{37}$ described that in his CSR definition, the economic component is "what business does for itself" and the non-economic component

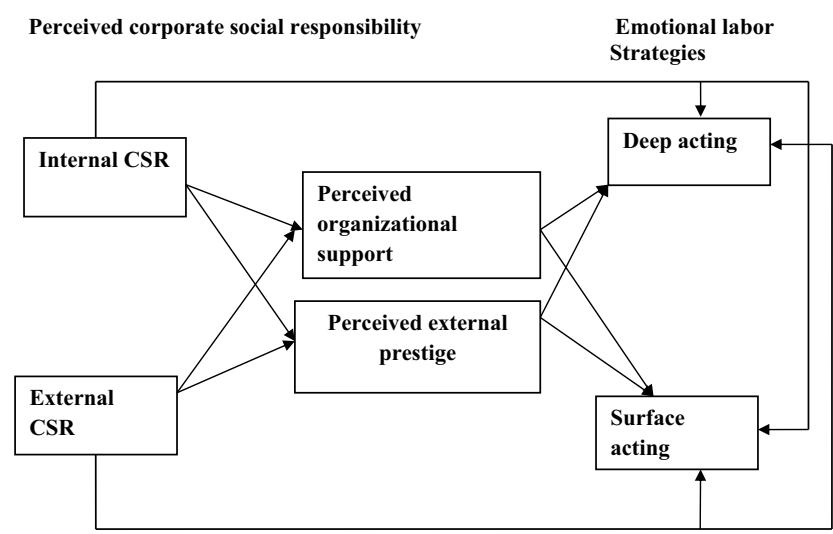

Figure I Conceptual model of the study showing all the variables and their relationships. is "what business does for others." Turker ${ }^{19}$ criticized Carroll's justification of the economic component, he argues that it is the basic motivation for the existence of a business, as profit is the primary objective.

The majority of the CSR framework is developed based on the expectations of multiple stakeholders, such as social and non-social stakeholders (ie, community, environment, employees, and customers. ${ }^{19}$

Scholars expressed that the distinction between internal CSR that incorporates empathy, support, emotional and welfare of the employees as well as the external CSR that includes safeguarding the environment and firm's involvement in society on workforce perceptions. Yet, this differentiation is important as it may be reason to cause a differential influence on workforce outcomes. ${ }^{39}$ The recipient of CSR activities could be either internal or external, as a result CSR scholars often conceptualized these activities as internal and external CSR. ${ }^{18}$ Internal CSR is "self-directed" and external CSR is "other-focused," dissimilarly influencing the attitude and behavior of employees. ${ }^{18}$ External corporate social responsibility is

A concept whereby companies integrate social and environmental concerns in their business operations and in their interaction with their stakeholders on a voluntary basis.

It focuses on the organization's ethical responsibility toward its external stakeholders like community, consumers, environment, and employees. ${ }^{31}$

Many productive businesses focus on "how to satisfy the consumer" or "how to support workforce", however, it is necessary to generalize the concept based on

"how to satisfy our stakeholders". The purpose for being for many of the companies is that they fulfill certain needs in their external world. ${ }^{40}$ It could include activities like environment and wildlife protection, support for humanitarian causes and volunteerism programs, and customer care programs. These initiatives reflect characteristics that are highly valued and recognized by the community.${ }^{17,18}$ External CSR initiatives are philanthropic and community-based contributions that enhance the organization's

reputation in the society. ${ }^{41}$ Stakeholders (ie, external) tend to value and recognize such practices especially when they are the intended beneficiaries of such activities This is also why organizations often try to enhance awareness of their CSR practices. ${ }^{42}$

Internal CSR measures are "policies and practices that are directly related to the physical and psychological 
working environment of an organization" ${ }^{43}$ Employees are salient stakeholders of an organization, ${ }^{11}$ instrumental for gaining competitive advantage. ${ }^{44}$ Internal CSR focuses on the internal operations of the organization relating to its employees, including training and development programs, good working conditions, organizational justice, health and safety programs for employees, diversity, and rewards. ${ }^{41,43}$

Internal CSR activities are no longer limited by what is culturally expected and practices that are "beyond compliance" with normative rules of organizational justice, they focuson personal and career development of employees, ${ }^{17}$ beyond the fundamental legal obligation of $\mathrm{HRM}^{45}$ Monetary compensation is inadequate, employees demand appreciation, and recognition in the form of respect from their employer. Further, Hameed et $\mathrm{al}^{18}$ contend that internal CSR positively impacts employees' attitudes and behaviors.

Operationalization of CSR in such categories is effective in distinguishing CSR initiatives specific to the target. ${ }^{16}$ Stakeholders outside the organization are beneficiaries of external CSR, whereas internal CSR activities are in the interest of incumbent employees. ${ }^{8}$ Although existing micro-CSR literature classifies employees' perception of their organization's internal and external CSR as a unit of differentiation, these constructs are further differentiated on the belief of whether these actions are beneficial to self or others. ${ }^{17}$ The current study recognizes the distinctive nature of these activities as a milestone to identify the mechanism through which different types of CSR activities influence emotional labor; and propose a multi-stakeholder view of emotional labor conditioned to the target of CSR activities.

Abrams and $\mathrm{Hogg}^{46}$ presented the social identity theory in 1970s, and the central precept of the theory directs that group/team conduct arises from a mutual feeling of social category membership, which has further led to many exciting advances in the literature. The concepts of SIT mainly revolves around motivational and cognitive procedures in group performance, group's identity and regulation of motivational conducts and inter-group social relationships. ${ }^{46}$ SIT evidently connects with CSR in the past literature. ${ }^{47-51}$ For instance, CSR is essential for male and female employees concerning organizational commitment drawing on SIT. ${ }^{41}$ Moreover, customer loyalty was enhanced through CSR and SIT with a major role of identity salience. ${ }^{52}$ Covering a wide array of impacts SIT also influences EL significantly. ${ }^{53-55}$ Based on this evidence, this study explores the SIT's connection with CSR and aims to explore the relationships between employee perception, perceived external prestige, and employees' EL, which was overlooked in past studies.

\section{Corporate Social Responsibility and Emotional Labor}

A fundamental basis of our study model is that CSR is a potential contributor to employee emotional labor. ${ }^{20}$ The initiator of the term "emotional labor", defined as the "management of feeling to create a publicly observable facial and bodily display". ${ }^{56}$ According to the Morris and Feldman ${ }^{57}$ definition, it is an individual's deliberate and directed efforts by expressing emotions required to be exhibited at work. As an employee's internal emotional state varies from what is required at the organization, it can be modified by practicing emotional labor, either deep or surface acting. ${ }^{25,53,58}$ The difference between these emotions is the grounds of authenticity and reliability during interaction with customers. ${ }^{59,60}$

The dramaturgical perspective is well suited to conceptualize the difference between deep and surface action, where the actor (ie, incumbent employee) acts (ie, perform his/her duties) on stage (ie, at workplace) for spectators (ie, clients).${ }^{61}$ Surface acting requires employees to suppress their felt emotion to display affective emotions, while deep acting requires employees to alter their inner feeling to match organizational display rules. ${ }^{56,59,62}$ Surface acting could be considered as managing emotions superficially (ie, suppression), ${ }^{63}$ while deep acting could be regarded as feeling the actual emotion (ie, mental reappraisal). ${ }^{53}$ Researchers argued that choosing surface acting over deep could probably have detrimental effects on both employees and organization. Thus, the organizations are required to enhance the understanding of deep acting among employees and encourage them to avoid thoughts that lead to surface acting during their interaction with customers. ${ }^{64}$

According to the social exchange theory, the two parties exchange benefit with each other, one individual provides the benefits and the other responds to it by offering some value. ${ }^{65}$ Scholars stated that such type of exchanges are applicable to CSR. As organizations take the responsibility of overall perspectives, other economic or legal benefits for the welfare of workforce as well as customers, the organizational members may reciprocate benefit in return to an entity. Further, CSR activities of the organization indicate the characteristics of the organization. Thus, if an entity emphasizes on both 
internal as well as external stakeholders while designing CSR practices, it demonstrates that an entity is benevolent, caring, and generous and will keep maintaining a empathetic nature in the future. Such expectations build considerate acts between the staff of an entity and these staff care and assist those who need their help. Thus, the staff reciprocate their considerate act. In such a manner, employees help an entity to minimize diverse institutional conflicts. In line with this, if the anticipations for the emotional content of an association are not fulfilled, members could be anticipated to become less considerate and committed towards their work and would reciprocate less.

Corporate social responsibility has been projected as an apparently visible indication that employees observe in the evaluation of distinctiveness and attractiveness of their employer. ${ }^{66}$ CSR activities consist of voluntary actions of organizations for the welfare of important stakeholders. These activities could be highly valued by their intended beneficiaries. Consequently, organizations with higher levels of social responsibility are expected to be perceived as prominent, attractive, valued, and as a source of self-esteem for employees. ${ }^{15}$ Employees, therefore, are expected to modify their internal feelings to match the organization's principles and standard operating procedures. It implies that if employees rate their organization at the higher end of the spectrum of social responsibility, such stronger identification enables them to match their feelings with emotional display rules to facilitate organizational success. Essentially, CSR is expected to strongly influence the employee's choice of an appropriate emotional labor strategy. ${ }^{20}$

Hypothesis 1a: Employee perception of external CSR is likely to positively impact Deep Acting.

Hypothesis 1b: Employee perception of external CSR is likely to negatively impact Surface Acting.

Hypothesis 2a: Employee perception of internal CSR is likely to positively impact Deep Acting.

Hypothesis 2b: Employee perception of internal CSR is likely to negatively impact Surface Acting.

Although the aforementioned literature has distinguished internal and external $\mathrm{CSR}^{8,18}$ their underlying mechanisms and differential effects to employee's attitudes and behaviors has rarely been examined. ${ }^{17,18}$ When employees monitor their organization's social responsibility actions, interested parties: source (ie, organization) and target (beneficiary of the action) impact employee's perceptions, attitudes, and behaviors depending on the source and target. ${ }^{67}$ In both types of CSR, the organization is the "source", however, the "target" is different. This difference is pivotal in gaining understanding of how employees react to CSR activities directed toward different stakeholders. ${ }^{17}$

\section{Differential Mechanisms: Prestige and Organizational Support}

Smidts et $\mathrm{al}^{68}$ defined external prestige as employee perception of an organization's social status in the view of external stakeholders.Occasionally, labeled as organizational image, ${ }^{69}$ it

Is based upon the individual's evaluation of the extent to which organizational outsiders hold the firm in high regard or esteem because of the positive, socially valued characteristics of the organization. $^{70}$

According to social identity perspective, self-definition of an individual is significantly relevant to the membership of a social unit (ie, organization). ${ }^{51}$ According to this theory, if an organization perceives to have differential characteristics from others, members strongly identify with the organization and comply with its rules and regulation. ${ }^{26,51,52}$ More importantly, heightened identification influences employees to involve in behaviors that are beneficial for the organization, because they believe organizational wellbeing as their own. ${ }^{51}$

It is apparent that corporations engaged in environmentally and socially responsible activities have a strong corporate credibility. ${ }^{71,72}$ Demonstrating specific attributes which are esteemed by external stakeholders adds to the identity building of organizational members and raises workforce self-confidence and esteem. ${ }^{69,73,74}$ In line with this, employees working in well reputable organizations makes them feel proud to be part of such organization that rises their self-esteem. ${ }^{75}$ Corroborating this, prior studies have demonstrated that organization's CSR activities affect workforce perceptions of external prestige. ${ }^{76,77}$

Individuals tend to enhance and retain their self-esteem developed through a sense of belonging to a social group. ${ }^{78,79}$ Perception of organizational image is vital in determining employees' response to organizational requirements. ${ }^{69}$ Further, Tyler and Blader ${ }^{80}$ contend that perceived external prestige serves as an instigator to motivate employees to perform consistent with the significance of that prestige to them. Hence, CSR activities directed toward external stakeholders are expected to engender positive perception external prestige.

Hypothesis 3: Employee perception of external CSR is likely to positively contribute to employee's perception of external prestige. 
Perceived organizational support is the employees' perception of the level at which they are valued and how important their wellbeing is to the organization. ${ }^{80,81}$ Conceptually, perception of support is developed through employees' aptitude to consider the organization as a human being. ${ }^{82}$ Flagship scholars in the domain of perceived organizational support propose that employees reciprocate the behavior received from the organization. This norm of reciprocity is derived from the social exchange theory. ${ }^{83}$

According to Blau, ${ }^{83}$ the premise of an exchange could either be social or economic in nature. Mutual trust is the base for any relationship that pertains goodwill, a gesture that will be reciprocated in the future. The benefits exchanged could be appreciated initially because they exhibit the strengths of a quid quo pro relationship; exchange of support as relevant to the parties concerned in the exchange. Since organizational support comprises of establishing a suitable working environment, ${ }^{80}$ it prompts motivation among employees to reciprocate through their efficient discharge of duties and contributions toward their organization. Therefore, CSR activities directed toward internal stakeholders (ie, employees) are expected to engender positive perception organizational support.

Hypothesis 4: Employee perception of internal CSR is likely to positively contribute to employee's perception of perceived organizational support.

Both perceptions (ie, prestige and support) serve to fulfill employee's self-enhancement and self-esteem as they encompass employees' belief regarding the perception of organization in view of external and internal stakeholders. ${ }^{17,55}$ These beliefs are the consequence of different sets of cues related to different targets referenced above. Prestige perceptions are indicated by organizational attributes of higher regards by external parties, ${ }^{69}$ whereas support perceptions are indicated by the cautious efforts made by organizations to support employees; that their wellbeing is of strategic importance to the organization. ${ }^{23}$

\section{Perceived External Prestige: Underlying Mechanism for External CSR Impact on Emotional Labor}

Mechanisms relevant to the CSR impact on employee attitudes and behaviors still requires plenty of research and attention in terms of relevant mediators and moderators. ${ }^{2}$ Client attitudes towards the company are linked with the corporate image of the business. ${ }^{84}$ The current study proposes external CSR as an important source of positive perception of external image, and that external image (ie, perceived external prestige) as a mechanism for external CSR activities' impact on emotional labor. If employees observe their organization's active participation toward a social cause (ie, community services), they tend to develop a positive social image of their organization based on external stakeholders' view. Research suggests that community development and philanthropy enhance outsiders' perception of the firm. ${ }^{85,86}$

Therefore, organizations often utilize their energies to confirm that their initiatives toward external stakeholders are highly visible and well recognized by the community especially when communities are the potential recipients of these initiatives. ${ }^{87}$ In particular, external CSR entails attributes highly regarded by society that boost perceived external prestige, which people assess through prominent cues prevailing within the society. Employees analyze outsider's word of mouth, direct advertising, outsider company-controlled reading material, and internal communication cues to identify the outsider's perception of firm's CSR activities. ${ }^{68}$ Following these cues, employees compare the distinct and high impact practices of their organization with other firms while evaluating prestige. ${ }^{69,88}$

Perceived external prestige is an important factor to enhance employees' self-conception and self-worth, ${ }^{89}$ especially when employees believe in the distinctiveness of their organization. ${ }^{69}$ Scholars stated that workforce perceiving positive external prestige would have high positive emotions during their tasks and the association. Based on the social exchange theory reciprocity principle, perceived external prestige of the company cannot be explicitly offered to workers. Organizations ensure workforce perception of positive external prestige by establishing a positive picture in the eyes of external stakeholders. ${ }^{77}$

Advocates of social identity theory posit that individuals tend to be a part of a prestigious organization to shift their self-esteem to a higher order of spectrum. ${ }^{90}$ In an organizational perspective, higher self-esteem of employees is an important consequence of positive external prestige. ${ }^{91,92}$

The studies of Hameed et $\mathrm{al}^{18}$ and Farooq et $\mathrm{al}^{17}$ have already used perceived external prestige as a mediating mechanism for the relationship between external CSR and organizational identification and have explained its nurturing effect toward employees' outcomes (ie, organizational identification). Further, perceived external prestige has also been linked with emotional labor directly or through an identification mechanism. ${ }^{64,93}$ However, Mishra ${ }^{55}$ suggested that there could be an inverse relationship between 
emotional labor and organizational identification (previously organizational identification and emotional labor, which means management of expressions (ie, emotional labor) could serve as a mechanism for explaining attitudes and behaviors developed at the workplace.

Oh et $\mathrm{al}^{20}$ investigated the CSR perception impact on emotional labor strategies through moral identity and organizational commitment and reported the ample effect of perceived CSR on emotional labor, directly and through the mechanism. The researchers further suggested investigating other mediating mechanisms of this relationship. Therefore, identifying factors (ie, external CSR and perceived external prestige) that influence emotional labor strategies to nurture effective attitudes and behaviors at the workplace could be a potential research insight. Therefore, positive external prestige developed through external CSR activities is expected to influence employee's choice of emotional labor.

Hypothesis 5: Perceived external prestige is likely to mediate between employee perception of external CSR and deep acting (which means perceived external prestige is likely to positively mediate between employee external CSR perception and deep acting negatively to surface acting).

\section{Perceived Organizational Support: Underlying Mechanism for Internal CSR Impact on Emotional Labor}

Employees identify the appeal of their organization in comparison to other organizations through the social support that is extended toward their employees. Emotional labor engenders positive outcomes when employees observe that their organization is providing social support. ${ }^{23}$ Perceived organizational support is an exchange between employees and organization. ${ }^{94}$ These exchange relationships are based on a basic reciprocity norm which influences the beneficiary to return the care, benefit, and support offered by the counterpart. ${ }^{95}$ Considering this as a relationship between organization and employee, support from one party (ie, organization or employee) influences the other to reciprocate similarly for the benefit of the original party. ${ }^{81}$

Employees evaluate the level of support from an organization based on indicators which reflect that they are members with high value and regard to the social group. ${ }^{96}$ The meta-analysis of Colquitt et $\mathrm{al}^{97}$ revealed that organizational support perception is related with enhanced job satisfaction, commitment toward organization, positive evaluation of authorities, and organizational citizenship behavior. Eisenberger et $\mathrm{al}^{98}$ observe that organizational support perception of employees engenders cognitive obligation to reciprocate beneficial acts, thereby improving commitment. Further, such support (ie, perceived organizational support) has been argued to be a trigger for emotional labor aligned with emotional-display rules at work. ${ }^{23,55,99}$

Rhoades and Eisenberger ${ }^{81}$ also argued that policies and practices of organization enhance employees' positive cognition such as perception of organizational support. Earlier literatures on corporate social responsibility ${ }^{17}$ and perceived organizational support prominently highlighted the potential of perceived organizational support as an underlying mechanism for employee attitudinal and behavioral outcomes. ${ }^{94}$ Further, Ruppet al ${ }^{100}$ also proposed that CSR effects can be way beyond the direct effect on employee attitudes and behaviors, as perceived organizational support and distributive justice could be potential outcomes.

Internal CSR activities in favor of employees, targeting their wellbeing and career development, sends signals and cues of the organization's inclination toward the importance of their well-being, ${ }^{63,66}$ hence an important trigger for organizational support perception. ${ }^{100}$ The psychological climate is employees' perception about the psychological safety (ie, supportive management) and meaningfulness at their workplace. ${ }^{101,102}$

As climate is affected by CSR-perception, ${ }^{38}$ it can lead to the establishment of climate of support to enhance employee perception of organizational support. This proposition has tangential support from Glavas and Kelley ${ }^{8}$ that revealed perceived organizational support as a potential mediator of CSR-employee outcomes relationship; when the purpose is to differentiate the "first party effects" of CSR (ie, effects from internal CSR) from "third party effects" (ie, effects from external CSR) on employee's job satisfaction and organizational commitment. Thus, internal CSR initiatives aiming at employee development are expected to produce perception of organizational support and increase the probability of their organizationally desired emotional display. ${ }^{103}$

Hypothesis 6: Perceived organizational support is likely to mediate between employee perception of internal CSR and emotional labor which means perceived organizational support is likely to positively mediate the relationship between internal CSR perception of employees and deep acting negatively to surface acting. 


\section{Methods}

\section{Samples and Procedures}

Data was collected from front-line employees of banks in Pakistan. We believe the banking services sector for data collection is relevant because this sector has a huge contribution in the economy, employees have direct and regular interaction with customers, and they are required to regulate their emotions. Therefore, our focus was on front-line employees and other personnel were excluded for data collection. We collected data through a selfadministered questionnaire. Furthermore, to reduce the common method bias, we collected data in two rounds with a lag time of 2 months between each round of data collection. The lag time of 2 months reduces the common method bias, as employees do not usually remember their previous responses and cannot relate them to the current responses. ${ }^{112}$ A code was placed on each questionnaire to match the data collected in different rounds and from different sources. ${ }^{113}$ Thus, to reduce CMB, the data was gathered by splitting the questionnaire into two parts, following the measures of Podsakoff et al. ${ }^{104}$ By considering the recommendations of Gurlek and Ugyur, and Gurlek and Tuna, ${ }^{77,105}$ we segregated our variable measures in two questionnaires to make a psychological separation. In the first questionnaire, we included the variables of CSR and perceived organizational support. We collected data of perceived external prestige, emotional labor dimensions, and demographic variables through the second questionnaire.

We calculated the sample size by using a Rao soft sample size calculator, with a five percent margin of error and $95 \%$ confidence interval, based on which, sample size was 381 for a population of 40,635 employees. Similarly, Sekaran and Bougie ${ }^{106}$ suggested that when population size is between 40,000 to 50,000 then sample size should be 381 (p. 294). Finally, we distributed 450 questionnaires to collect data and received 421 useable responses, out of which 376 responses were selected after initial screening. The respondents were $62.5 \%$ male, while $37.5 \%$ were female. The average age of the respondents was over 33 years with an average experience of 6 years. Furthermore, $55 \%$ of the respondents were graduates and $45 \%$ were post-graduates.

\section{Measurements}

To avoid social desirability bias, a cover letter was included in each questionnaire containing the brief introduction about the purpose of data collection and a surety statement regarding the confidentiality and anonymity of respondent's information. The questionnaires were designed in a way to adapt all measurement scales from the literature. The assessment was made using a five-point Likert scale ranging from 1 ("strongly disagree") to 5 ("strongly agree").

\section{Perceived External CSR}

We measured perceived external CSR using Turker's ${ }^{19}$ sevenitems scale $(\alpha=0.940)$. A sample item was "Our Company supports organizations working in a problematic area".

\section{Perceived Internal CSR}

Five items were adapted from Turker ${ }^{19}$ to measure internal CSR (CSR toward employees). A sample item was "My company policies encourage employees to develop their skills and careers". Internal consistency reliability of perceived internal CSR was 0.913 .

\section{Perceived External Prestige}

This was measured by using eight-items scale adapted from Mael and Ashforth. ${ }^{89}$ A sample item was "My employer is considered one of the best". The reliability of perceived external prestige was 0.908 .

\section{Perceived Organization Support}

The eight-item scale adapted from Eisenberger et $\mathrm{al}^{107}$ was used to measure perceived organization support, where a sample item was "my organization strongly considers my goals and values" $(\alpha=0.920)$.

\section{Deep Acting}

It was measured using four items adapted from Diefendorff et $\mathrm{al}^{108}$ where a sample item was "I work hard to feel the emotions that I need to show to customers". Internal consistency reliability of deep acting was 0.900 .

\section{Surface Acting}

It was measured using seven items adapted from Diefendorff et $\mathrm{al}^{108}$ where a sample item was "I fake the emotions I show when dealing with customers" $(\alpha=0.907)$.

\section{Results}

\section{Measurement Model}

We used confirmatory factor analysis (CFA) in order to assess the reliability and validity of our measurement model, comprising perceived external CSR, perceived internal CSR, perceived external prestige, two dimensions of emotional labor (ie, surface acting and deep acting), and 
perceived organizational support. Firstly, we measured item reliability based on their factor loadings on respective constructs. We considered 0.6 as a threshold value in order to include or exclude items from the scale, ${ }^{109,110}$ this process lead to elimination of two items from perceived organizational support: "My organization would forgive an honest mistake on my part" and "If given the opportunity, my organization would take advantage of me". Similarly, two items were eliminated from perceived external prestige: "People look down at my employer" and "Former employees of my company would be proud to have their children work here". Secondly, Cronbach alpha coefficients was measured to confirm the construct reliability. Table 1 depicts that all values of Cronbach alpha were greater than the concerned threshold value 0.7. ${ }^{109}$ Thirdly, for convergent analysis, we calculated average variance extracted (AVE) and found all values greater than threshold point $0.5,{ }^{109}$ which confirm the convergent validity of measures. Furthermore, we compared the squared root of AVE of each construct and its correlations with other constructs. Table 1 summarizes the correlation between constructs and square root of AVE in diagonals within brackets. Fornell and Larcker ${ }^{111}$ argued that square root of AVE should be greater than the paired correlation which consequently confirms the discriminant validity. Moreover, we analyzed measurement model against various indices for its fitness like $\chi^{2}=540.892 ; \mathrm{df}=351 ; \chi^{2} / \mathrm{df}=1.541$; RMSEA $=0.056 ; \quad$ GFI $=0.94 ; \quad$ CFI $=0.93 ; \quad$ IFI $=0.93$, $\mathrm{NFI}=0.91$, and all were accordingly found to be a good fit for the model. ${ }^{112}$

\section{Common Method Bias}

There are several methods to confirm common method bias as applied by Gürlek, and Uygur recently. Harman single factor test was employed to fix the issue of common method bias. Single factor explained a variance of $26.81 \%$ which was lower than our default model-explained variance $(68.2 \%)$. According to Podsakoff et $\mathrm{al}^{104}$ no single factor should demonstrate more than $50 \%$ variance, otherwise it will confirm the common method biasness existence. ${ }^{104}$ Hence, this proves that the proposed theoretical model is statistically fit and therefore structural equation modeling (SEM) can be applied for hypotheses testing.

\section{Mediation Test}

Structural equation modeling (SEM) was utilized to determine the effect of perceived internal and external CSR on employees' emotional labor through mediation of perceived external prestige and perceived organizational support. The proposed theoretical model was tested by using Smart PLS 3.0 which is based on a partial least square algorithm. Initially, we checked the direct relationships of perceived external CSR with perceived organizational support and perceived internal CSR with perceived external prestige. We found these relationships to be insignificant and problematic in the fitness of the model, and therefore we removed these paths from the model. Subsequently, we analyzed structural model fitness against various indices for its fitness like $\chi^{2}=589.421 ; \mathrm{df}=349 ; \chi^{2} / \mathrm{df}=1.688$; RMSEA $=0.051 ; \quad$ GFI $=0.93 ; \quad$ CFI $=0.89 ; \quad \mathrm{IFI}=0.92$, $\mathrm{NFI}=0.90$, and all were found according to good fit of the model. ${ }^{85}$ The first and second hypotheses were developed to check the direct effect of perceived external and internal CSR on dimensions of emotional labor (ie, surface acting and deep acting). Both hypotheses were not supported by the results and found to be insignificant. Thhe third hypothesis was developed to determine the positive effect of perceived external CSR on perceived external prestige and results significantly supported the hypothesis. Similarly, the fourth hypothesis was proposed to check the impact of perceived internal CSR on perceived organizational support and the result fully supported this hypothesis as a positive relationship. The fifth hypothesis was

Table I Descriptive Statistics and Tests for Convergent and Discriminant Validity

\begin{tabular}{|l|l|l|l|l|l|l|l|l|l|l|}
\hline Variables & Mean & SD & AVE & A & I & $\mathbf{2}$ & $\mathbf{3}$ & $\mathbf{4}$ & $\mathbf{5}$ & $\mathbf{6}$ \\
\hline Deep acting & 3.48 & 1.10 & 0.769 & 0.900 & $\mathbf{0 . 8 7 7}$ & & & & \\
Perceived external CSR & 3.46 & 1.04 & 0.736 & 0.940 & $0.767^{* *}$ & $\mathbf{0 . 8 5 8}$ & & & \\
Perceived external prestige & $3.5 \mathrm{I}$ & 0.97 & 0.667 & 0.908 & $0.749^{* *}$ & $0.855^{* *}$ & $\mathbf{0 . 8 1 7}$ & & \\
Perceived internal CSR & 3.40 & 1.10 & 0.742 & 0.913 & $0.74 I^{* *}$ & $0.810^{* *}$ & $0.767^{* *}$ & $\mathbf{0 . 8 6 I}$ & & \\
Perceived organizational support & 3.48 & 1.02 & 0.715 & 0.920 & $0.785^{* *}$ & $0.790^{* *}$ & $0.783^{* *}$ & $0.85 I^{* *}$ & $\mathbf{0 . 8 4 5}$ & \\
Surface acting & 2.86 & 0.99 & 0.642 & 0.907 & $-0.500^{* *}$ & $-0.525^{* *}$ & $-0.506^{* *}$ & $-0.519^{* *}$ & $-0.528^{* *}$ & $\mathbf{0 . 8 0 2}$ \\
\hline
\end{tabular}

Notes: Diagonal elements (bold values) in the correlation matrix are the square root of the average variance extracted values. For adequate discriminant validity, each element should be greater than it's corresponding off-diagonal correlation coefficients. $* * P<0.01$. 
Table 2 Direct and Indirect Effects (via Perceived External Prestige and Perceived Organizational Support) of Perceived External and Internal CSR on Emotional Labor (Surface Acting)

\begin{tabular}{|c|c|c|c|c|c|c|}
\hline \multirow[t]{2}{*}{ Factors } & \multirow{2}{*}{$\begin{array}{l}\text { Perceived External } \\
\text { Prestige }^{\mathbf{a}}\end{array}$} & \multirow{2}{*}{$\begin{array}{l}\text { Perceived } \\
\text { Organizational Support }\end{array}$} & \multicolumn{4}{|c|}{ Surface Acting ${ }^{\mathbf{b}}$} \\
\hline & & & $\begin{array}{l}\text { Direct Effect } \\
\text { C Path }\end{array}$ & $\begin{array}{l}\text { Indirect } \\
\text { Effect }\end{array}$ & $\begin{array}{l}\text { Total } \\
\text { Effect }\end{array}$ & $\begin{array}{l}\text { Type of } \\
\text { Mediation }\end{array}$ \\
\hline $\begin{array}{l}\text { Perceived external } \\
\text { CSR }\end{array}$ & $0.865 * * *$ & ns & ns & $-0.206 * * *$ & $-0.206 * * *$ & Full \\
\hline Perceived internal CSR & ns & $0.86 I^{* * *}$ & ns & $-0.294 * * *$ & $-0.294 * * *$ & Full \\
\hline $\begin{array}{l}\text { Perceived external } \\
\text { prestige }\end{array}$ & & & $-0.239 * * *$ & & & \\
\hline $\begin{array}{l}\text { Perceived } \\
\text { organizational support }\end{array}$ & & & $-0.342^{* * *}$ & & & \\
\hline
\end{tabular}

Notes: Values reported are standardized regression weights. ns=non-significant (relationship tested but found to be non-significant thus removed for subsequent hypotheses testing). C path=direct effect of independent variable. ${ }^{a}$ Mediator ${ }^{b}$ Dependent variable. ${ }^{*} * *_{p}<0.00 \mathrm{I}$.

Table 3 Direct and Indirect Effects (via Perceived External Prestige and Perceived Organizational Support) of Perceived External and Internal CSR on Emotional Labor (Deep Acting)

\begin{tabular}{|l|l|l|l|l|l|l|}
\hline Factors & $\begin{array}{l}\text { Perceived External } \\
\text { Prestige }^{\mathbf{a}}\end{array}$ & $\begin{array}{l}\text { Perceived Organizational } \\
\text { Support }\end{array}$ & \multicolumn{2}{l|}{ Deep Acting } \\
\cline { 2 - 7 } & Direct & Direct & $\begin{array}{l}\text { Direct Effect } \\
\text { C Path }\end{array}$ & $\begin{array}{l}\text { Indirect } \\
\text { Effect }\end{array}$ & $\begin{array}{l}\text { Total } \\
\text { Effect }\end{array}$ & $\begin{array}{l}\text { Type of } \\
\text { Mediation }\end{array}$ \\
\hline Perceived external CSR & $0.865^{* * *}$ & $\mathrm{~ns}$ & $\mathrm{~ns}$ & $0.300^{* * *}$ & $0.300^{* * *}$ & Full \\
\hline Perceived internal CSR & $\mathrm{ns}$ & $0.861^{* * *}$ & $\mathrm{~ns}$ & $0.442^{* * *}$ & $0.442^{* * *}$ & Full \\
\hline $\begin{array}{l}\text { Perceived external } \\
\text { prestige }\end{array}$ & & & $0.347^{* * *}$ & & & \\
\hline $\begin{array}{l}\text { Perceived } \\
\text { organizational support }\end{array}$ & & & $0.514^{* * *}$ & & & \\
\hline
\end{tabular}

Notes: Values reported are standardized regression weights. ns=non-significant (relationship tested but found to be non-significant thus removed for subsequent hypotheses testing). $\mathrm{C}$ path=direct effect of independent variable. ${ }^{\mathrm{a}}$ Mediator ${ }^{\mathrm{b}}$ Dependent variable. ${ }^{*} * * * 0.00 \mathrm{I}$.

developed to check the mediation effect of perceived external prestige between perceived external CSR and employees' emotional labor (ie, surface acting and deep acting) and the results confirmed the existence of a negative indirect effect of perceived external CSR on surface acting and positive indirect effect of perceived external CSR on deep acting and these effects were found to be significant which supports the proposed hypothesis. Similarly, the sixth hypothesis was developed to check the mediation effect of perceived organizational support between perceived internal CSR and employees' emotional labor (ie, surface acting and deep acting) and these results were also found to be significant, suggesting that perceived internal CSR has a negative indirect effect on employees' surface acting and a positive indirect effect on employees' deep acting. Conclusively, all paths (except the direct relationship of perceived internal and external CSR with emotional labor) were found to be significant. This demonstrates the existence of mediations between perceived internal and external CSR and employees' emotional labor. Tables 2 and 3 depict the results of direct and indirect effects of SEM.

\section{Discussion and Conclusion Discussion}

Based on our findings, this study shows that perceived external CSR positively developed perceived external prestige which in result enhances employees' deep acting 
and reduces employees' surface acting. Similarly, perceived internal CSR positively enhances perceived organizational support which encourages employees' deep acting and diminishes the employees' surface acting at front-line workplace. Furthermore, our study elaborates that employees show similar concern toward CSR practices, and either these are internal or external. Finally, our findings suggest that both internal and external CSR practices induce a kind of emotional attachment of all stakeholders with the organization. Similarly, in the case of employees who form emotional attachment with the organization, this attachment helps them to manage their emotions at front-line workplace in the favor of organization.

This research was aimed to determine the way emotional labor of employees works favorably in the presence of external and internal CSR. It is an emerging, yet debatable subject matter among researchers and practitioners. Besides, emotional labor becomes more pivotal in the services sector because of its nature of direct interaction with customers. Correspondingly, banking is a major segment of services sector, and CSR practices are practiced more actively here. ${ }^{113}$ Therefore, the study is focused on this rapidly growing sector because emotions of frontline employees lead to alter customers' response toward organization. ${ }^{93}$ Furthermore, researchers have argued that CSR practices affect employees' behaviors and emotions, ${ }^{8,93}$ the mechanism underlying these relationships are still undermined. Thus, we contribute in the development of new pathways under the light of social identity and exchange theories by testing the proposed model.

Particularly, we contribute to the literature by measuring CSR in two separate categories (ie, internal and external) by exploring the relationship mechanisms: how the perception of CSR among employees leads them to manage their emotions at the workplace, especially in dealing with direct customers. Furthermore, we revealed that positive perception of internal CSR encourages employees to manage their emotions via perceived organizational support. Similarly, the positive perception of external CSR builds positive emotional labor through perceived external prestige. Moreover, we showed that both types of CSR (ie, internal and external) not only enhance the deep acting among employees, but they also diminish the element of surface acting from employees working at the front line of the organization. The revelation of these intervening mechanisms elucidates how CSR and employees' emotional labor are related, and it also highlights how underlying mechanisms will be helpful in the effective management of CSR practices.

\section{Theoretical Contributions}

In addition to the said contributions in the literature of CSR, our study provides fresh insight into the social exchange and identity theories. First, this study reveals how two different types of CSR are associated with employee's emotion regulation factors that are linked to emotional labor. In doing so, we anticipated surface and deep acting strategies play important roles in the link between CSR and employee's service in banking industry, as this financial sector heavily depends upon the services offered and requires a high positive display of emotions to build image and reputation. Second, we contribute to the literature under the light of social exchange theory that perceived organizational support strongly predicts employees' emotional labor which diminishes the myth that prestige is the only factor to influence employees' emotions at workplace. Third, we contribute to the literature of CSR by unveiling the mediating role of POS by infusing social exchange theory; our results indicated that perceived external prestige does not have a significant negative effect on surface acting. ${ }^{93}$ Our results confirm that the perception of external prestige significantly and negatively affects employees' surface acting. This result is supported by the argument that employees care about the prestige of their organization and do not want to harm this prestige by their fake emotions, which diminish the element of surface acting among employees. There may be many reasons for doing so, such as job security, nature of socialization, job responsibility, religious intervention, job as obligation, and intensity of collectivism. Finally, our research is the first of its kind which unearths different mechanisms of internal and external CSR to emotional labor in a unified framework under the umbrella of social identity and exchange theories.

\section{Practical Implication}

The results of this research also suggest that a workforce with high degrees of motivation are more likely to alter their innermost thoughts when dealing with clients and as a result reflect performance that exceeds the anticipated expectations. To put it another way, the workforce with high motivation in an entity are more capable of performing and rendering better services. Thus, organizational 
leaders should cultivate and motivate employees to achieve efficiency. Given this, transformational leadership can be favorable as it consists of compassionate feelings, charismatic and emotions-based leadership that can build strong feelings of mutual identity and enhances employee's enthusiasm to show positive emotions at work. ${ }^{114,115}$ These findings may provide an aid to managers for initiating CSR practices which serve organization externally and internally.

\section{Limitations and Future Directions}

Our study is not free of limitations. We used a crosssectional design to collect data which made us less confident in drawing strong inferences about our variables. Moreover, we collected data from only one source which may increase the effect of common method bias in our results. However, we employed different pre- and post-remedies of data collection for minimization of common method bias as suggested by Podsakoff et al. ${ }^{104}$ Furthermore, our data is based on self-reporting of respondents which may generate social-desirability bias, however to overcome this issue we ensured the anonymity of respondents' information. We limit our proposed model only to emotional labor, but in the future consequences of emotional labor strategies (eg, job satisfaction, emotional exhaustion) may be included to make this relationship more meaningful and practical. So, future studies may examine effects of emotional labor strategies on employees, caused by perceived internal and external CSR. Subsequently, researchers may study other antecedents of emotional labor strategies such as meaningfulness of work, work characteristics, and personal factors like emotional intelligence, employee's emotional stability.

\section{Ethics Statement}

This study was carried out in accordance with the recommendations of the Ethical Principles of Psychologists and Code of Conduct by the American Psychological Association's (APA). All participants gave written informed consent in accordance with the Declaration of Helsinki. The protocol was approved by the Ethics Committee of the Lahore Business School, University of Lahore, Lahore, Pakistan.

\section{Disclosure}

The authors report no conflicts of interests in this work.

\section{References}

1. Aguinis H, Glavas A. What we know and don't know about corporate social responsibility: a review and research agenda. $J$ Manage. 2012;38(4):932-968. doi:10.1177/0149206311436079

2. Glavas A. Corporate social responsibility and organizational psychology: an integrative review. Front Psychol. 2016;7(144):1-13. doi:10.3389/fpsyg.2016.00144

3. Lee MDP. A review of the theories of corporate social responsibility: its evolutionary path and the road ahead. Int J Manag Rev. 2008;10(1):53-73. doi:10.1111/j.1468-2370.2007.00226.x

4. Lockett A, Moon J, Visser W. Corporate social responsibility in management research: focus, nature, salience and sources of influence. J Manag Stud. 2006;43(1):115-136. doi:10.1111/ j.1467-6486.2006.00585.x

5. Margolis JD, Walsh JP. Misery loves companies: rethinking social initiatives by business. Adm Sci Q. 2003;48(2):268-305. doi: $10.2307 / 3556659$

6. Orlitzky M, Schmidt FL, Rynes SL. Corporate social and financial performance: a meta-analysis. Organ Stud. 2003;24(3):403441. doi: $10.1177 / 0170840603024003910$

7. Bhattacharya CB, Korschun D, Sen S. Strengthening stakeholdercompany relationships through mutually beneficial corporate social responsibility initiatives. J Bus Ethics. 2009;85(2):257272. doi:10.1007/s10551-008-9730-3

8. Glavas A, Kelley K. The effects of perceived corporate social responsibility on employee attitudes. BEQ. 2014;24(2):165-202. doi: $10.5840 /$ beq20143206

9. Clarkson ME. A stakeholder framework for analyzing and evaluating corporate social performance. Acad Manag Rev. 1995;20 (1):92-117. doi:10.5465/amr.1995.9503271994

10. Nigel M, Suprawan L. Most valuable stakeholders: the impact of employee orientation on corporate financial performance. Public Relat Rev. 2012;38(2):280-287. doi:10.1016/j.pubrev.2011.11.006

11. Greenwood M, Anderson E. 'I used to be an employee but now I am a stakeholder': implications of labelling employees as stakeholders. Asia Pac J Hum Resour. 2009;47(2):186-200. doi:10.1177/1038411109105441

12. Stites JP, Michael JH. Organizational commitment in manufacturing employees: relationships with corporate social performance. Bus Soc. 2011;50(1):50-70. doi:10.1177/0007650310394311

13. Valentine S, Fleischman G. Ethics programs, perceived corporate social responsibility and job satisfaction. J Bus Ethics. 2008;77 (2):159-172. doi:10.1007/s10551-006-9306-z

14. Jones DA, Willness CR, Madey S. Why are job seekers attracted by corporate social performance? Experimental and field tests of three signal-based mechanisms. Acad Manag J. 2014;57(2):383404. doi:10.5465/amj.2011.0848

15. Farooq O, Payaud M, Merunka D, Valette-Florence P. The impact of corporate social responsibility on organizational commitment: exploring multiple mediation mechanisms. $J$ Bus Ethics. 2014;125(4):563-580. doi:10.1007/s10551-013-1928-3

16. Farooq M, Farooq O, Jasimuddin SM. Employees response to corporate social responsibility: exploring the role of employees' collectivist orientation. Eur Manag J. 2014;32(6):916-927. doi:10.1016/j.emj.2014.03.002

17. Farooq O, Rupp DE, Farooq M. The multiple pathways through which internal and external corporate social responsibility influence organizational identification and multifoci outcomes: the moderating role of cultural and social orientations. Acad Manag J. 2017;60(3):954-985. doi:10.5465/amj.2014.0849

18. Hameed I, Riaz Z, Arain GA, Farooq O. How do internal and external CSR affect employees' organizational identification? A perspective from the group engagement model. Front Psychol. 2016;7(788):1-13. doi:10.3389/fpsyg.2016.00788 
19. Turker D. How corporate social responsibility influences organizational commitment. J Bus Ethics. 2009;89(2):189-204. doi:10.1007/s10551-008-9993-8

20. Oh SH, Hwang Y, Kim H. Is deep acting prevalent in socially responsible companies? The effects of CSR perception on emotional labor strategies. Front Psychol. 2019;10:308. doi:10.3389/ fpsyg. 2019.00308

21. Malik K. Employee Labour Techniques Used by the Bankers of Pakistan: A Cross Gender Study. 2018.

22. Hülsheger UR, Schewe AF. On the costs and benefits of emotional labor: a meta-analysis of three decades of research. J Occup Health Psychol. 2011;16(3):361-389. doi:10.1037/a0022876

23. Hur W-M, Han S-J, Yoo -J-J, Moon TW. The moderating role of perceived organizational support on the relationship between emotional labor and job-related outcomes. Manag Decis. 2015;53(3):605-624. doi:10.1108/MD-07-2013-0379

24. Brotheridge CM, Lee RT. Development and validation of the emotional labour scale. J Occup Organ Psychol. 2003;76 (3):365-379. doi:10.1348/096317903769647229

25. Humphrey RH, Ashforth BE, Diefendorff JM. The bright side of emotional labor. $J$ Organ Behav. 2015;36(6):749-769. doi:10.1002/job.2019

26. Grandey AA, Gabriel AS. Emotional labor at a crossroads: where do we go from here? Annu Rev Organ Psychol Organ Behav. 2015;2(1):323-349. doi:10.1146/annurev-orgpsych-032414111400

27. Mishra SK. Perceived external prestige and employee outcomes: mediation effect of organizational identification. Corp Reput Rev. 2013;16(3):220-233. doi:10.1057/crr.2013.9

28. Zulfiqar S, Sadaf R, Popp J, Vveinhardt J, Máté D. An examination of corporate social responsibility and employee behavior: the case of Pakistan. Sustainability. 2019;11(13):3515. doi:10.3390/ su11133515

29. Cornelius N, Todres M, Janjuha-Jivraj S, Woods A, Wallace J. Corporate social responsibility and the social enterprise. $J$ Bus Ethics. 2008;81(2):355-370. doi:10.1007/s10551-007-9500-7

30. Mueller K, Hattrup K, Spiess S-O L-HN. The effects of corporate social responsibility on employees' affective commitment: a cross-cultural investigation. J Appl Psychol. 2012;97(6):11861200. doi:10.1037/a0030204

31. El Akremi A, Gond J-P, Swaen V, De Roeck K, Igalens J. How do employees perceive corporate responsibility? Development and validation of a multidimensional corporate stakeholder responsibility scale. J Manage. 2018;44(2):619-657. doi:10.1177/ 0149206315569311

32. Carroll AB. Carroll's pyramid of CSR: taking another look. Int J Corp Soc Responsib. 2016;1(1):1-8. doi:10.1186/s40991-0160004-6

33. Dahlsrud A. How corporate social responsibility is defined: an analysis of 37 definitions. Corp Soc Responsib Environ Manag. 2008;15(1):1-13. doi:10.1002/csr.132

34. Matten D, Moon J. "Implicit" and "explicit" CSR: a conceptual framework for a comparative understanding of corporate social responsibility. Acad Manage Rev. 2008;33(2):404-424. doi:10.5465/amr.2008.31193458

35. Jamali D. A stakeholder approach to corporate social responsibility: a fresh perspective into theory and practice. J Bus Ethics. 2008;82(1):213-231. doi:10.1007/s10551-007-9572-4

36. Jamali D, Safieddine AM, Rabbath M. Corporate governance and corporate social responsibility synergies and interrelationships. Corp Govern Int Rev. 2008;16(5):443-459. doi:10.1111/j.14678683.2008.00702.x

37. Carroll AB. A three-dimensional conceptual model of corporate performance. Acad Manag Rev. 1979;4(4):497-505. doi:10.5465/ amr.1979.4498296
38. Aguilera RV, Rupp DE, Williams CA, Ganapathi J. Putting the S back in corporate social responsibility: a multilevel theory of social change in organizations. Acad Manag Rev. 2007;32 (3):836-863. doi:10.5465/amr.2007.25275678

39. Hur WM, Moon TW, Choi WH. When are internal and external corporate social responsibility initiatives amplified? Employee engagement in corporate social responsibility initiatives on prosocial and proactive behaviors. Corp Soc Responsib Environ Manag. 2019;26(4):849-858. doi:10.1002/csr.1725

40. Freeman RE, Velamuri SR. A new approach to CSR: company stakeholder responsibility. In: Corporate Social Responsibility. Springer; 2006:9-23.

41. Brammer S, Millington A, Rayton B. The contribution of corporate social responsibility to organizational commitment. Int $J$ Hum Resour Manag. 2007;18(10):1701-1719. doi:10.1080/ 09585190701570866

42. Du S, Bhattacharya $\mathrm{CB}$, Sen S. Maximizing business returns to corporate social responsibility (CSR): the role of CSR communication. Int J Manag Rev. 2010;12(1):8-19. doi:10.1111/j.14682370.2009.00276.x

43. Turker D. Measuring corporate social responsibility: a scale development study. $J$ Bus Ethics. 2009;85(4):411-427. doi:10.1007/s10551-008-9780-6

44. Dohnalová Z, Zimola B. Corporate stakeholder management. Procedia Soc Behav Sci. 2014;110:879-886. doi:10.1016/j. sbspro.2013.12.933

45. Dupont C, Ferauge P, Giuliano R. The impact of corporate social responsibility on human resource management: GDF SUEZ's case. Int Bus Res. 2013;6(12):145-155. doi:10.5539/ibr. v6n $12 \mathrm{p} 145$

46. Abrams DE, Hogg MA. Social Identity Theory: Constructive and Critical Advances. Springer-Verlag Publishing; 1990.

47. Hu B, Liu J, Zhang X. The impact of employees' perceived CSR on customer orientation: an integrated perspective of generalized exchange and social identity theory. Int J Contemp Hosp Manag. 2020;32(7):2345-2364. doi:10.1108/IJCHM-10-2019-0822

48. Albasu J, Nyameh J. Relevance of stakeholders theory, organizational identity theory and social exchange theory to corporate social responsibility and employees performance in the commercial banks in Nigeria. J Bus Econ Manag. 2017;4(5):95-105.

49. Korschun D, Bhattacharya C, Sen S. Using corporate social responsibility to strengthen employee and customer relationships. ACR Asia Pac Adv. 2009.

50. Azim MT. Corporate Social Responsibility and employee behavior: mediating role of organizational commitment. Rev Bras de Gestao de Negocios. 2016;18(60).

51. He J, Zhang H, Morrison AM. The impacts of corporate social responsibility on organization citizenship behavior and task performance in hospitality. Int J Contemp Hosp Manag. 2019;31 (6):2582-2598. doi:10.1108/IJCHM-05-2018-0378

52. Marin L, Ruiz S, Rubio A. The role of identity salience in the effects of corporate social responsibility on consumer behavior. J Bus Ethics. 2009;84(1):65-78. doi:10.1007/s10551008-9673-8

53. Ashforth BE, Humphrey RH. Emotional labor in service roles: the influence of identity. Acad Manag Rev. 1993;18(1):88-115. doi:10.5465/amr.1993.3997508

54. Zhang Q, Zhu W. Exploring emotion in teaching: emotional labor, burnout, and satisfaction in Chinese higher education. Commun Educ. 2008;57(1):105-122. doi:10.1080/03634520701586310

55. Mishra SK. Linking perceived organizational support to emotional labor. Pers Rev. 2014;43(6):845-860. doi:10.1108/PR-092012-0160

56. Hochschild AR. The Managed Heart: Commercialization of Human Feeling. Univ of California Press; 2012. 
57. Morris JA, Feldman DC. The dimensions, antecedents, and consequences of emotional labor. Acad Manag Rev. 1996;21(4):9861010. doi:10.5465/amr.1996.9704071861

58. Allen JA, Diefendorff JM, Ma Y. Differences in emotional labor across cultures: a comparison of Chinese and US service workers. $J$ Bus Psychol. 2014;29(1):21-35. doi:10.1007/s10869-013-9288-7

59. Grandey AA. Emotional regulation in the workplace: a new way to conceptualize emotional labor. J Occup Health Psychol. 2000;5 (1):95-110. doi:10.1037/1076-8998.5.1.95

60. Kruml SM, Geddes D. Exploring the dimensions of emotional labor: the heart of Hochschild's work. Manag Commun $Q$. 2000;14(1):8-49. doi:10.1177/0893318900141002

61. Grove SJ, Fisk RP. The service experience as theater. $A C R N A m$ Adv. 1992;19(1):455-462.

62. Gabriel AS, Daniels MA, Diefendorff JM, Greguras GJ. Emotional labor actors: a latent profile analysis of emotional labor strategies. J Appl Psychol. 2015;100(3):863-879. doi: $10.1037 / \mathrm{a} 0037408$

63. Zapf D. Emotion work and psychological well-being: a review of the literature and some conceptual considerations. Hum Resour Manag Rev. 2002;12(2):237-268. doi:10.1016/S1053-4822(02)00048-7

64. Mishra SK, Bhatnagar D, D'cruz P, Noronha E. Linkage between perceived external prestige and emotional labor: mediation effect of organizational identification among pharmaceutical representatives in India. J World Bus. 2012;47(2):204-212. doi:10.1016/j. jwb.2011.04.007

65. Gergen KJ. Social exchange theory in a world of transient fact. Behav Theor Soc. 1977;91-114.

66. Carmeli A, Gilat G, Waldman DA. The role of perceived organizational performance in organizational identification, adjustment and job performance. J Manag Stud. 2007;44(6):972-992. doi:10.1111/j.1467-6486.2007.00691.x

67. Lavelle JJ, Rupp DE, Manegold J, Thornton MA. Multifoci Justice and Target Similarity: Emerging Research and Extensions. The Oxford Handbook of Justice in Work Organizations; 2015:165-186.

68. Smidts A, Pruyn ATH, Van Riel CB. The impact of employee communication and perceived external prestige on organizational identification. Acad Manag J. 2001;44(5):1051-1062.

69. Dutton JE, Dukerich JM, Harquail CV. Organizational images and member identification. Adm Sci Q. 1994;39(2):239-263. doi: $10.2307 / 2393235$

70. Fuller JB, Hester K, Barnett T, Frey L, Relyea C, Beu D. Perceived external prestige and internal respect: new insights into the organizational identification process. Hum Relat. 2006;59(6):815-846

71. Boğan E, Dedeoğlu BB. Hotel employees' corporate social responsibility perception and organizational citizenship behavior: perceived external prestige and pride in organization as serial mediators. Corp Soc Responsib Environ Manag. 2020;27 (5):2342-2353. doi:10.1002/csr.1996

72. Su L, Huang S, van der Veen R, Chen X. Corporate social responsibility, corporate reputation, customer emotions and behavioral intentions: a structural equation modeling analysis. JCTR. 2014;10(4):511-529. doi:10.1080/19388160.2014.958606

73. Chaudhary R, Akhouri A. CSR perceptions and employee creativity: examining serial mediation effects of meaningfulness and work engagement. Soc Responsib J. 2019;15(1):61-74. doi:10.1108/SRJ-01-2018-0018

74. Kim H-R, Lee M, Lee H-T, Kim N-M. Corporate social responsibility and employee-company identification. J Bus Ethics. 2010;95(4):557-569. doi:10.1007/s10551-010-0440-2

75. Rodrigo P, Aqueveque C, Duran IJ. Do employees value strategic CSR? A tale of affective organizational commitment and its underlying mechanisms. Bus Ethics. 2019;28(4):459-475. doi: $10.1111 /$ beer. 12227
76. De-Roeck K, Delobbe N. Do environmental CSR initiatives serve organizations' legitimacy in the oil industry? Exploring employees' reactions through organizational identification theory. $J$ Bus Ethics. 2012;110(4):397-412. doi:10.1007/s10551-012-1489-x

77. Gürlek M, Tuna M. Corporate social responsibility and work engagement: evidence from the hotel industry. Tour Manag Perspect. 2019;31:195-208. doi:10.1016/j.tmp.2019.05.004

78. Shamir B. Calculations, values, and identities: the sources of collectivistic work motivation. Hum Relat. 1990;43(4):313-332. doi:10.1177/001872679004300402

79. Turner JC, Oakes PJ. The significance of the social identity concept for social psychology with reference to individualism, interactionism and social influence. Br J Soc Psychol. 1986;25 (3):237-252. doi:10.1111/j.2044-8309.1986.tb00732.x

80. Eisenberger R, Stinglhamber F, Vandenberghe C, Sucharski IL, Rhoades L. Perceived supervisor support: contributions to perceived organizational support and employee retention. J Appl Psychol. 2002;87(3):565-573. doi:10.1037/0021-9010.87.3.565

81. Rhoades L, Eisenberger R. Perceived organizational support: a review of the literature. $J$ Appl Psychol. 2002;87(4):698-714. doi:10.1037/0021-9010.87.4.698

82. Levinson H, Levinson H. Reciprocation: the relationship between man and organization. In: Freedman AM, Bradt KH, editors. Consulting Psychology. 2009:31-47.

83. Blau PM. Exchange and Power in Social Life. New Brunswick; 1964.

84. Gürlek M, Düzgün E, Uygur SM. How does corporate social responsibility create customer loyalty? The role of corporate image. Soc Responsib J. 2017;13(3):409-427. doi:10.1108/SRJ10-2016-0177

85. Brammer S, Millington A. Firm size, organizational visibility and corporate philanthropy: an empirical analysis. Bus Ethics. 2006;15(1):6-18. doi:10.1111/j.1467-8608.2006.00424.x

86. Fryxell GE, Wang J. The fortune corporate 'reputation' index: reputation for what? J Manage. 1994;20(1):1-14. doi:10.1177/ 014920639402000101

87. Bhattacharya CB, Sen S, Korschun D. Using corporate social responsibility to win the war for talent. MIT Sloan Manag Rev. 2008;49(2):1-10.

88. Lee J, Park SY, Baek I, Lee C-S. The impact of the brand management system on brand performance in B-B and B-C environments. Ind Mark Manag. 2008;37(7):848-855. doi:10.1016/j.indmarman.2008.04.005

89. Mael F, Ashforth BE. Alumni and their alma mater: a partial test of the reformulated model of organizational identification. $J$ Organ Behav. 1992;13(2):103-123. doi:10.1002/job.4030130202

90. Van Dick R. Identification in organizational contexts: linking theory and research from social and organizational psychology. Int $J$ Manag Rev. 2001;3(4):265-283. doi:10.1111/14682370.00068

91. Benkhoff B. Ignoring commitment is costly: new approaches establish the missing link between commitment and performance. Hum Relat. 1997;50(6):701-726. doi:10.1177/ 001872679705000604

92. Ashforth BE, Mael F. Social identity theory and the organization. Acad Manag Rev. 1989;14(1):20-39. doi:10.5465/ amr.1989.4278999

93. Anwar F, Ahmed I, Waqas M, Ismail WKW, Islam T. Effects of external prestige on emotional labour: mediation by organisational identification and moderation by perceived organisational support. Middle East J Manag. 2019;6(2):186-203. doi:10.1504/ MEJM.2019.097816

94. Akoorie M, Ahmed I, Ismail WKW, Amin SM, Nawaz MM. A social exchange perspective of the individual guanxi network. Chinese Manag Stud. 2013;7(1):127-140. doi:10.1108/ 17506141311307640 
95. Gouldner AW. The norm of reciprocity: a preliminary statement. Am Sociol Rev. 1960;25(2):161-178. doi:10.2307/2092623

96. Hur WM, Moon TW, Jun JK. The role of perceived organizational support on emotional labor in the airline industry. Int J Contemp Hosp Manag. 2013;25(1):105-123. doi:10.1108/ 09596111311290246

97. Colquitt JA, Conlon DE, Wesson MJ, Porter CO, Ng KY. Justice at the millennium: a meta-analytic review of 25 years of organizational justice research. J Appl Psychol. 2001;86(3):425-445. doi:10.1037/0021-9010.86.3.425

98. Eisenberger R, Armeli S, Rexwinkel B, Lynch PD, Rhoades L. Reciprocation of perceived organizational support. $J \mathrm{Appl}$ Psychol. 2001;86(1):42-51. doi:10.1037/0021-9010.86.1.42

99. Kim HJ, Hur W-M, Moon T-W, Jun J-K. Is all support equal? The moderating effects of supervisor, coworker, and organizational support on the link between emotional labor and job performance. $B R Q \quad$ Bus Res Q. 2017;20(2):124-136. doi:10.1016/j. brq.2016.11.002

100. Rupp DE, Shao R, Thornton MA, Skarlicki DP. Applicants' and employees' reactions to corporate social responsibility: the moderating effects of first-party justice perceptions and moral identity. Pers Psychol. 2013;66(4):895-933. doi:10.1111/peps.12030

101. Brown SP, Leigh TW. A new look at psychological climate and its relationship to job involvement, effort, and performance. $J$ Appl Psychol. 1996;81(4):358-368. doi:10.1037/00219010.81.4.358

102. Zhiqiang M, Siddiqui SH, Khan MAS. Be aware not reactive: testing a mediated-moderation model of dark triad and perceived victimization via self-regulatory approach. Front Psychol. 2020;11(2141). doi:10.3389/fpsyg.2020.02141

103. Khan MAS, Du Jianguo AAH, Mushtaq TU, Usman M, Usman M. Affective commitment foci as parallel mediators of the relationship between workplace romance and employee job performance: a cross-cultural comparison of the People's Republic of China and Pakistan. Psychol Res Behav Manag. 2018;11:267. doi:10.2147/PRBM.S168542

104. Podsakoff N, MacKenzie SB, Lee J-Y, Podsakoff NP. Common method biases in behavioral research: a critical review of the literature and recommended remedies. J Appl Psychol. 2003;88 (5):879-903. doi:10.1037/0021-9010.88.5.879
105. Gürlek M, Uygur A. Service-oriented high-performance human resource practices and employee service performance: a test of serial mediation and moderation models. J Manag Organ. 2020;1-37. doi:10.1017/jmo.2020.8

106. Sekaran U, Bougie R. Research Methods for Business: A Skill Building Approach. John Wiley \& Sons; 2016.

107. Eisenberger R, Cummings J, Armeli S, Lynch P. Perceived organizational support, discretionary treatment, and job satisfaction. $J$ Appl Psychol. 1997;82(5):812-820. doi:10.1037/00219010.82.5.812

108. Diefendorff JM, Croyle MH, Gosserand RH. The dimensionality and antecedents of emotional labor strategies. J Vocat Behav. 2005;66(2):339-357. doi:10.1016/j.jvb.2004.02.001

109. Hair JF, Black WC, Babin BJ, Anderson RE, Tatham RL. Multivariate Data Analysis (Vol. 6): Pearson Prentice Hall Upper Saddle River. NJ; 2006.

110. Min J, Iqbal S, Khan MAS, Akhtar S, Anwar F, Qalati SA. Impact of supervisory behavior on sustainable employee performance: mediation of conflict management strategies using PLS-SEM. PLoS One. 2020;15(9):e0236650. doi:10.1371/journal. pone. 0236650

111. Fornell C, Larcker DF. Structural Equation Models with Unobservable Variables and Measurement Error: Algebra and Statistics. Los Angeles, CA: Sage Publications Sage CA; 1981.

112. $\mathrm{Hu} \mathrm{L}$, Bentler PM. Cutoff criteria for fit indexes in covariance structure analysis: conventional criteria versus new alternatives. Struct Equ Model. 1999;6(1):1-55. doi:10.1080/ 10705519909540118

113. Sharif M, Rashid K. Corporate governance and corporate social responsibility (CSR) reporting: an empirical evidence from commercial banks (CB) of Pakistan. Qual Quant. 2014;48(5):25012521. doi:10.1007/s11135-013-9903-8

114. Grant AM, Berg JM. Prosocial Motivation. 2012.

115. Khan MAS, Jianguo D, Usman M, Ahmad MI. Moderated mediation model of interrelations between workplace romance, wellbeing, and employee performance. Front Psychol. 2017;8:2158. doi:10.3389/fpsyg.2017.02158
Psychology Research and Behavior Management

\section{Publish your work in this journal}

Psychology Research and Behavior Management is an international, peer-reviewed, open access journal focusing on the science of psychology and its application in behavior management to develop improved outcomes in the clinical, educational, sports and business arenas. Specific topics covered in the journal include: Neuroscience, memory and decision making; Behavior modification and management; Clinical applications; Business and sports performance management; Social and developmental studies; Animal studies. The manuscript management system is completely online and includes a very quick and fair peer-review system, which is all easy to use. Visit http://www. dovepress.com/testimonials.php to read real quotes from published authors. 